Membership support. Cathleen Bourdon helped many sections with their appointments and nominations process. Alia Al-Taqi prepared the ballots for the election. Plans for the April 18 Executive Committee meeting are underway. Kathy BriggsSmith began sending out appointment letters for Joe Boissé.
ALA cooperation. ACRL staff served on the ALA Job Evaluation Committee, the Data Processing Steering Committee, the Accounts Payable Task Force, the Payroll Task Force, the Orientation and Training Task Force, and the Hardware Task Force.-JoAn S. Segal.

\title{
ACRL programs in New Orleans
}

\section{This year's conference programs feature jazz, optical and compact discs, and government documents.}

\section{Anthropology and Sociology Section}

ANSS will host a behind-the-scenes tour of the Amistad Research Center and the Middle American Research Institute at Tulane University on Tuesday, July 12, 1:00-5:00 p.m., followed by a reception. To register, contact Lynne M. SchmelzKeil, Director of Development and Public Relations, Alexander Library, Rutgers University, New Brunswick, NJ 08903; (201) 932-7505.

\section{Art Section}

"Jazz in the Arts: Photography, Film, Dance, and Music Collections" (Monday, July 11, 9:30 a.m.-12:30 p.m.), cosponsored by the Music Library Association, will be a multimedia presentation on jazz arts, with demonstrations of collections of photographs, films and videos, dance materials, and recorded music. A range of issues on collecting jazz images and recordings will also be presented. Speakers include Curtis Jerde, curator of the Hogan Jazz Archive, Tulane University; Edward Manney, assistant curator, Vivian G. Harsch Collection of Afro-American History and Literature, Chicago Public Library; and Don Roberts, Independent Media, Minneapolis.

\section{Asian and African Section}

"Preservation of Asian and African Materials"
(Monday, July 11, 9:30 a.m.-12:30 p.m.), cosponsored by the International Relations Round Table and the RTSD Preservation of Library Materials Section, will discuss the current and future status of preservation in Asian/African area studies. Speakers include: Michael W. Albin, Library of Congress, on Middle Eastern materials; Gregory A. Finnegan, Dartmouth Library, on African materials; James H. Nye, University of Chicago, on South Asian materials; Diane E. Perushek, Princeton University, on East Asian materials; and Charles Bryant, Yale University, on Southeast Asian materials. Patricia Battin, president of the Commission on Preservation and Access, will serve as discussant.

\section{Audiovisual Committee}

"Microcomputer Software: What Is It? Why Do I Need It? What Do I Do With It Once I Get It?" (Saturday, July 9. 9:30 a.m.-12:30 p.m.), cosponsored by the RTSD and PLA Audiovisual Committees, will focus on the role that software plays in public and technical services. Special emphasis will be placed on practical recommendations. Among the speakers are Victor Rosenberg (Personal Bibliographic Software), on the future of library software development; Katherine Chiang and Samuel Demas (Cornell University), on software collection policy; and Jan DeSirey (Hennepin County Library), on cataloging. 


\section{Bibliographic Instruction Section}

“Teaching CD-ROM" (Sunday, July 10, 2:00-5:30 p.m.) will address integrating CD-ROM sources into bibliographic instruction. The scheduled speakers are: Randall Hensley (University of Washington) on user attitudes, expectations, and behaviors; Mara R. Saule (University of Vermont), on teaching strategies; Martin Kesselman and Deanna Nipp (Rutgers University), on instructional opportunities; Christina A. Brundage (San Jose State University), on point-of-use guides; Joe Jaros (Texas A\&M University), on individualized instruction; Fred Musto (Indiana University), on group workshops; and Andrea Wyman (SUNYOswego), on course-integrated instruction. A poster session follows the presentation. The Mimi Dudley BI Librarian of the Year Award will be presented at this session.

\section{College Libraries Section}

"Collection Development Issues in MediumSized and Smaller Academic Libraries" (Sunday, July 10, 9:30 a.m.-12:30 p.m.), cosponsored by the RTSD Resources Section, is aimed at the librarian with a library materials budget under $\$ 1$ million. Speakers include Craig S. Likness (Trinity University), "The Creative Use of Acquisitions Mechanisms"; Thomas W. Leonhardt (University of the Pacific), "Collection Development Outside ARL: Observations of a Newcomer"; Arthur H. Miller Jr. (Lake Forest College), "Will the Books We Buy Get Used?"; Rebecca T. Lenzini (Faxon), "Ten Years of Trends in Serials Prices.” William E. Hunnaford Jr. (Albright College) and Katina Strauch (College of Charleston) will present a debate on the topic, "Resolved: That it is the faculty, and not the librarians, who should be primarily responsible for selecting books for the library's general collection."

\section{Community and Junior College Libraries Section}

"Optical Disc Technology...And All That Jazz" (Saturday, July 9, 9:00-11:00 a.m.) will focus on developing trends in the use of state-of-the-art optical disc technology. The scheduled speakers are: John M. Cohn and Ann L. Kelsey (County College of Morris).

The section will be sponsoring a New Orleans Lagniappe Dinner on Friday, July 8, 6:30-10:00 p.m., at Kolbs, 125 St. Charles Avenue. Entertainment will be provided by local educator and humorist, Dr. C. "Lum" Ellis. Peggy Usner, a dancer in the film The Big Easy, and her Cajun Dance Troupe will demonstrate and teach Cajun dance steps. Tickets are $\$ 25$ by advance re:servation not later than June 24. Send check or money order payable to Lenora Lockett, 6141 S. Hermes St., New Orleans, LA 70126.

\section{Copyright Committee}

"Copyright Is Still with Us" (Monday, July 11, 9:30-11:00 a.m.) will be a panel presentation on copyright issues facing librarians. Panelists will be Wendell Barbour (Christopher Newport College), who will present an overview of copyright issues; Jim Bouras (president of the Motion Picture Licensing Corporation), on videotape copyright; David Ferriero (Massachusetts Institute of Technology), on interlibrary loan and photocopying issues; and John Garrett (Copyright Clearance Center), on software copyright issues. Sophia Galifaro of the Copyright Committee will moderate the discussion.

\section{Education and Behavioral Sciences Section}

"Accreditation Review Strategies in Education and Psychology" (Monday, July 11, 9:30-11:30 a.m.), cosponsored by AASL, will address the role of libraries, collections, and education/behavioral sciences librarians in preparing for accreditation review by organizations such as NCATE. Two of the three speakers will be Ursula Delworth (College of Education, University of Iowa) and Stephen Bensman (Louisiana State University).

\section{English and American Literature Discussion Group}

"The Literary Byte: Research in the Online Age" (Menday, July 11, 9:00-11:00 a.m.) will examine the use and availability of CD technology in the humanities.

\section{Law and Political Science Section}

"Information Policies of International Organizations: Roadblocks to Access" (Sunday, July 10, 2:00-4:00 p.m.), cosponsored by the Government Documents Round Table and the International Documents Task Force, will aim at instilling in the audience a better understanding of the difficulties international organizations and their users face in obtaining and using timely and accurate information. Kate E. Adams (University of NebraskaLincoln) will serve as panel moderator. Panelists will include Gilles-André Gosselin (Organisation for Economic Co-operation and Development), Nellie Moffitt (Readex), Adeno Addis (Law School, Loyola University), and Robert W. Schaaf (UN and International Documents, Library of Congress). All four speakers will discuss the factors of timeliness and currency and the availability of information in electronic format.

\section{Rare Books and Manusc:ipts Section}

"Government Documents As Rare Books" (Sunday, July 10, 2:00-5:30 p.m.), cosponsored by GODORT and MAGERT, will present the problems of identifying rare government documents in gen- 
eral and documents collections and explore strategies for protecting and preserving these materials. Speakers will be: Robert S. Martin (Louisiana State University), David Heisser (Tufts University), Richard Landon (University of Toronto), Donna P. Koepp (University of Kansas), and Nora J. Quinlan (University of Colorado at Boulder).

\section{Science and Technology Section}

"Libraries Without Walls: Emerging Technologies and Practical Information Access" (Tuesday, July 12, 9:00 a.m.-12:30 p.m.), will address such questions as: Can libraries control the information explosion? Are we slipping as technology surges forward? Keynote speaker will be Robert Hayes, dean of the UCLA Graduate School of Library and Information Science. Discussion sessions will feature Beth Warner (Louisiana State University), Helen Josephine (Arizona State University), Con-

\section{Other programs}

Electronic Library Development in Academic Libraries Discussion Group. This group will hold a round table discussion on current topics in electronic library development (Saturday, July $9,11: 30$ a.m.-2:00 p.m.).

English and American Literature Discussion Group. "The Literary Byte: Research in the Online Age" (Monday, July 11, 9:00-11:00 a.m.) will examine the use and availability of CD technology in the humanities.

Home Economics/Human Ecology Librarians Discussion Group. "Collection Development and Bibliographic Instruction in Home Economics/Human Ecology Libraries" (Sunday, July 10, 4:30-5:30 p.m.).

Research Discussion Group. "ACRL's Role in Supporting Research by Academic Librarians" (Monday, July 11, 9:30-11:00 a.m.) will feature three speakers on the role ACRL should play in supporting the research efforts of academic librarians: Joan Durrance (University of Michigan SLIS), Kathy Jackson (Texas A\&M), and Sharon Rogers (George Washington University).

Undergraduate Librarians Discussion Group. "Self-Service Information" (Monday, July 11, 9:30 a.m.-12:30 p.m.) will feature presentations on "SourceFinder" by Mary Beth Allen and Joyce Wright; "QPrompt" by Dana Smith; and "Hypercard" by Monica Ertel.

"WHCLIS II: How to Get Glitz and Guts from the Process" (Saturday, July 9, 2:00-4:00 p.m.), sponsored by many ALA units. Speakers Peggy Barber, William Asp, Robbie Kurland, and Cecil P. Beach will describe the White House Conference process and how it gives each state a unique opportunity to reach future goals and win new advocates among the public and elected officials. stance Miller (Indiana University), David Kohl (University of Colorado), and Henry Schafer (North Carolina State University).

\section{Slavic and East European Section}

"New Technology for Slavic and East European Librarianship" (Sunday, July 10, 2:00-4:00 p.m.) will focus on bibliographic and non-bibliographic commercial databases, and the creation and application of local databases using mainframes and micros. Speakers will be Harold Leich (Library of Congress), Christina Jaremko (UCLA SLIS), Stephen Corrsin (Brooklyn College), and Robert Karlowich (Pratt Institute SLIS).

\section{University Libraries Section}

"Nurturing the Plant to Root: Retention of the Academic Librarian" (Saturday, July 9, 2:00-4:00 p.m.), cosponsored by the LAMA Personnel Administration Section, will feature a panel presentation on issues related to retention of academic and research librarians in the profession and by individual institutions. Panelists will be James G. Neal (Pennsylvania State University), Jordan M. Scepanski (California State University, Long Beach), and Melissa D. Trevvett (CLR Professional Development Program).

The ULS Current Topics Discussion Group will present a program on "Building the Electronic Library: Providing Access to Databases through the Online Catalog" (Sunday, July 10, 9:00-11:00 a.m.), focusing on the online catalog as the framework for providing enhanced campus access to resources in electronic format. Representatives of three libraries that have recently loaded databases will discuss the decision-making, planning, and technical perspectives. Scheduled speakers are Flo Wilson (Vanderbilt University), Sandra Card (California Institute of Technology), and Patricia Renfro (University of Pennsylvania).

\section{Western European Specialists Section}

"Strangers in New Worlds: Migration Studies in Europe and America" (Monday, July 11, 9:30 a.m.-12:30 p.m.), cosponsored by the Anthropology and Sociology Section, will link the history of Europeans in America with the migrant populations in Europe. The program will assess trends in research and the resulting demands on library collections and services. Speakers include: Dino Cinel (Department of History, Tulane University), Mark J. Miller (Department of Political Science, University of Delaware), and Joel Wurl (Immigration History Research Center, University of Minnesota). Respondents will be Carol Armbruster (Library of Congress), Helen MacLam (Choice), and Susanne Roberts (Yale University).

\section{Women's Studies Section}

WSS will cosponsor with a number of other ALA 
units a program on "The Creation of Patriarchy: Its Implications for Librarianship" (Monday, July 11, 2:00-5:30 p.m.). Gerda Lerner, author of Cre- ation of Patriarchy, will speak on patriarchy. Sharon Hogan will discuss the implications for female academic librarians.

\section{ACRL meetings in New Orleans}

\section{A tentative schedule for ALA's New Orleans Conference,}

July 9-14, 1988.

\section{ACRL BOARD OF DIRECTORS}

Orientation breakfast: Saturday, July 9, 8:00-9:00 a.m.

First meeting: Saturday, July 9, 2:00-4:00 p.m.

Second meeting: Tuesday, July 12, 2:00-5:30 p.m.

Executive Committee and Section Officers luncheon: Sunday, July 10, 12:30-2:00 p.m.

Joint meeting with Budget \& Finance and

Planning Committees: Friday, July 8, 4:30-5:30 p.m.

Orientation for new Committee Chairs and new

Section Officers breakfast: Sunday, July 10, 7:30-9:00 a.m.

\section{ACRL GENERAL}

President's Program/Membership: Monday, July 11, 2:00-5:30 p.m.

\section{ACRL DIVISIONAL COMMITTEES}

Academic Library Statistics: Saturday, July 9, 8:00-9:00 a.m.; Monday, July 11, $11: 30$ a.m. $-12: 30$ p.m.

Academic Status: Saturday, July 9, 2:00-4:00 p.m.; Monday, July 11, 9:00-11:00 a.m.; Tuesday, July 12, 9:00-11:00 a.m.

Academic Status-Hearing on Guidelines: Sunday, July 10, 8:00-10:00 p.m.

ACRL/AECT Joint Committee on Two-Year Colleges: Friday, July 8, 9:30 a.m.-12:30 p.m. Audiovisual: Sunday, July 10, 9:00-11:00 a.m. Awards Task Force: Monday, July 11, 9:00-11:00 a.m.
Budget and Finance: Saturday, July 9, 8:00 a.m. $-12: 30$ p.m.; Sunday, July 10, 8:00 a.m.-12:30 p.m., 2:00-5:30 p.m.

Conference Program Planning-Dallas, 1989: Tuesday, July 12, 8:00-9:00 a.m.

Constitution and Bylaws: Saturday, July 9, 8:00-11:00 a.m.; Monday, July 11, 8:00-11:00 a.m.

Continuing Education Courses Advisory: Tuesday, July 12, 9:30 a.m.-12:30 p.m.

Copyright: Saturday, 11:30 a.m.-12:30 p.m.

Copyright-Program: Monday, July 11, 9:30-11:00 a.m.

Extended Campus Library Services Guidelines: Saturday, July 9, 8:00-10:00 p.m.; Sunday, July 10, 8:00-10:00 p.m.; Tuesday, July 12, 9:00-11:00 a.m.

Historically Black College and University Library Project: Tuesday, July 12, 9:00-11:00 a.m.

International Relations Task Force: Tuesday, July 12, 8:00-9:00 a.m.

Legislation: Saturday, July 9, 9:00-11:00 a.m.; Monday, July 11, 2:00-4:00 p.m.

Legislation-Program: Sunday, July 10, 2:00-4:00 p.m.

Librarians as Instructors Task Force: Saturday, July 9, 8:00-9:00 a.m.; Sunday, July 10, 8:00-9:00 a.m.; Monday, July 11, 8:00-9:00 a.m.

Libraries and Computer Centers Task Force: Saturday, July 9, 11:30 a.m.-12:30 p.m.

Library Access Task Force: Saturday, July 9, 11:30 a.m.-12:30 p.m.; Sunday, July 10, 9:00-11:00 a.m.; Tuesday, July 12, 9:00-11:00 a.m. 